\title{
Age of Jack mackerel Trachrus murphyi (Carangidae) using daily growth rings in sagittae otoliths
}

\section{Edad de jurel Trachurus murphyi (Carangidae) usando incrementos diarios en otolitos sagittae}

\author{
Lilian Cisterna ${ }^{1} \&$ Hugo Arancibia ${ }^{2, *}$ \\ ${ }^{1}$ Departamento de pesquerías, Instituto de Investigación Pesquera, Talcahuao, P.O. 4270789, Chile. \\ 2Departament of Oceanography, Faculty of Natural Sciences and Oceanography, Universidad de Concepción, P.O. BOX 160- \\ C, Concepción, Chile. \\ *Corresponding author: harancib@udec.cl
}

\begin{abstract}
Growth of Jack mackerel (Trachurus murphyi) was estimated using daily growth rings in fish collected in central-south Chile from 2004 to 2011. The von Bertalanffy growth curve at length for both sexes ( $\mathrm{n}=210$ individuals) is $F L_{t}=75^{*}\left[1-e^{-0.16(t+0.13)}\right]$ where $\mathrm{FL}_{\mathrm{t}}$ is fork length $(\mathrm{cm})$ at time $\mathrm{t}$ (years).
\end{abstract}

Keywords: age, Chile, daily growth rings, Jack mackerel, sagittae otoliths, Trachurus murphyi.

\section{RESUMEN}

Se estimó el crecimiento del jurel (Trachurus murphyi) usando anillos de crecimiento diario en peces colectados en Chile centro-sur desde 2004 hasta 2011. La curva de crecimiento en longitud de von Bertalanffy para sexos conjuntos ( $\mathrm{n}=210$ individuos) es $F L_{t}=75^{*}\left[1-e^{-0,16(t+0,13)}\right]$ donde $\mathrm{LH}_{\mathrm{t}}$ es la longitud horquilla (cm) a tiempo t (años).

Palabras clave: anillos de incremento diario, Chile, edad, jurel, Trachurus murphyi.

Trachurus murphyi (Nichols, 1920) is a mid-size pelagic fish species distributed mainly in the South Eastern Pacific Ocean off Ecuador, Peru and Chile (Agafonov 1994). In the 1990s, it was also dispersed along the Subtropical Convergence Zone $\left(35^{\circ} \mathrm{S}\right.$ to $\left.50^{\circ} \mathrm{S}\right)$ in the so-called "Jack mackerel belt" from the Chilean coast to New Zealand (Grechina 1998; Sokolov \& Kusnetsov 1994). The peak of annual harvests of T. murphyi was 4.40 millions of tones in 1995 , which represented $89 \%$ of the total harvests in that year considering jointly the Chilean purse seine fleets (north and central-south), the Peruvian purse seine fleet and the offshore mid-water trawling factory fleets. However, total harvests of T. murphyi in year 2014 were 395 thousand of tones, only (Table A4.1 in Anonimous, 2014).

Studies on age and growth in species that sustain fisheries are important in stock assessment models and management (Williams et al. 2013) in order to estimate abundance by ages. Besides, natural mortality (M) is an input for stock assessment and is frequently estimatedas a function of the instantaneous coefficient of growth, K (Jensen, 1996; Hoenig 1983; Pauly 1980). The objective of this study was to estimate the parameters of the von Bertalanffy length growth equation for T. murphyi using daily growth rings in sagittae otoliths.

Annual growth ring counts in sagittae otoliths have been used to age individuals of T. murphy I (Aguayo et al. 1981; Pavez \& Saa 1978). But, mean ages for fish with 58 to 60 $\mathrm{cm}$ of fork length (FL) ranged from 8 to 16 years (Kochkin 1998). However, determining age in species of Trachurus may be complex, since the annual growth rings are difficult to interpret (Araya et al. 2001; Steward \& Ferrell 2001; Waldron \& Kerstan 2001). Panella (1971) developed a technique to determine age and daily growth rate in sagittae otoliths of Merluccius bilinearis. Later, Panella (1974) demonstrated that the annual marks detected in sagittae otoliths of marine species contain 365 daily increments, aproximately. For T. murphyi, Araya et al. (2003) validated experimentally the daily frequency of the micro-increments in sagittae otoliths.

210 right sagittae otoliths of T. murphyi, from 18 to $60 \mathrm{~cm} \mathrm{FL}$, were mounted in polyesther resin. Fish were 
collected from year 2004 to 2011 off central Chile. The aim was to follow a cohort during its pass in the fishery.

According to Morales-Nin (1991) and Green et al. (2009), sections in the sagittae otoliths of T. murphyi (thickness: $0.5 \mathrm{~mm}$ ) were obtained and later they were by hand polished (thickness: $0.3 \mathrm{~mm}$ ).

Daily growth increments in sagittae otoliths were seen under an Olympus CX31-RTSF-2 optical microscope $(1000 \mathrm{X})$ as alternately clear and dark concentric rings (Araya et al. 2003). Counts were performed following the radius of the otolith. The density of increments was counted using an ocular reticulate with 100 divisions. Following to Panfili \& Morales-Nin (2002), a scanning electron microscope (Center of Spectrometry and Electronic Microscopy, Universidad de Concepción, Chile) was used to observe daily increments.

The generalized von Bertalanffy equation of individual length growth is

$$
F L_{t}=F L_{\infty} *\left\lfloor 1-e^{-K\left(t-t_{0}\right)}\right\rfloor
$$

where $\mathrm{FL}_{\infty}(\mathrm{cm})$ is the theoretical maximum length or asimptotic length, $\mathrm{K}$ (year $\left.{ }^{-1}\right)$ is the instantaneous coefficient of growth, $\mathrm{t}_{0}$ (years) is the theoretical time at length 0 , and $\mathrm{t}$ is time (years). For species of Trachurus the fork length (FL) is used. Parameters were estimated with the software R $(\mathrm{R}$ Development Core Team. "R: A language and environment for statistical computing". R Foundation for Statistical Computing, Vienna, Austria. URL: http://www.R-project. org. 2004). In order to estimate better the parameter $K$ and to avoid bias, $\mathrm{FL}_{\infty}$ was estimated according to Taylor (1962 fide Pauly, 1983), who communicated that the oldest fish of a stock grow to reach about 95 percent asymptotic length. The largest individuals of T. murphyi sampled on board of industrial purse seine vessels operating off central Chile, in the period 2004-2011, had $71 \mathrm{~cm}$ FL. So, it was assumed that $71 \mathrm{~cm} \mathrm{FL}$ represents $95 \%$ of $\mathrm{FL}_{\infty}$, which means that $\mathrm{FL}_{\infty}$ is $\sim 75 \mathrm{~cm} \mathrm{FL}$.

The smallest daily increments in otolith were those close to the center (Fig. 1). The width of daily increments in the border of an otolith was $1.36 \mu \mathrm{m}$ in one fih of $51 \mathrm{~cm}$ FL, but near the border the width was $1.84 \mu \mathrm{m}$ (Fig. 2). The parameters of the von Bertalanffy length growth equation in T. murphyi are shown in Table 1 and the growth curve in Fig. 3.

Historically, the read of annual rings in entire otoliths has been used to determine the age in adults of T. murphyi, but considerable variations has been found. $\mathrm{K}$ values in this species have ranged from 0.07 year $^{-1}$ (Castillo \& Arrizaga 1987) to 0.14 year-1 $^{-1}$ (Kaiser 1973), likely due to the preparation technique used, difficulties in interpretation criteria of annual rings, and confusion with double and/ or false rings. However, Cubillos and Arancibia (1994) informed $\mathrm{K}=0.138$ year $^{-1}$ using the Wetherall (1986) method with 10 years of length-frequency data. Later, Cubillos and Grechina (1998) informed $\mathrm{K}=0.144$ year $^{-1}$ using the modal progression analysis seasonally from 1987 to 1992 . Comparatively, in the present study $\mathrm{K}=0.16$ year $^{-1}$, which is close similar to $\mathrm{K}=0.155$ year $^{-1}$ informed by Dioses (2013) with samples off Peru. Indirectly, with the present study are validated the Dioses' (2013) results, who had used correctly the technique of annual rings.
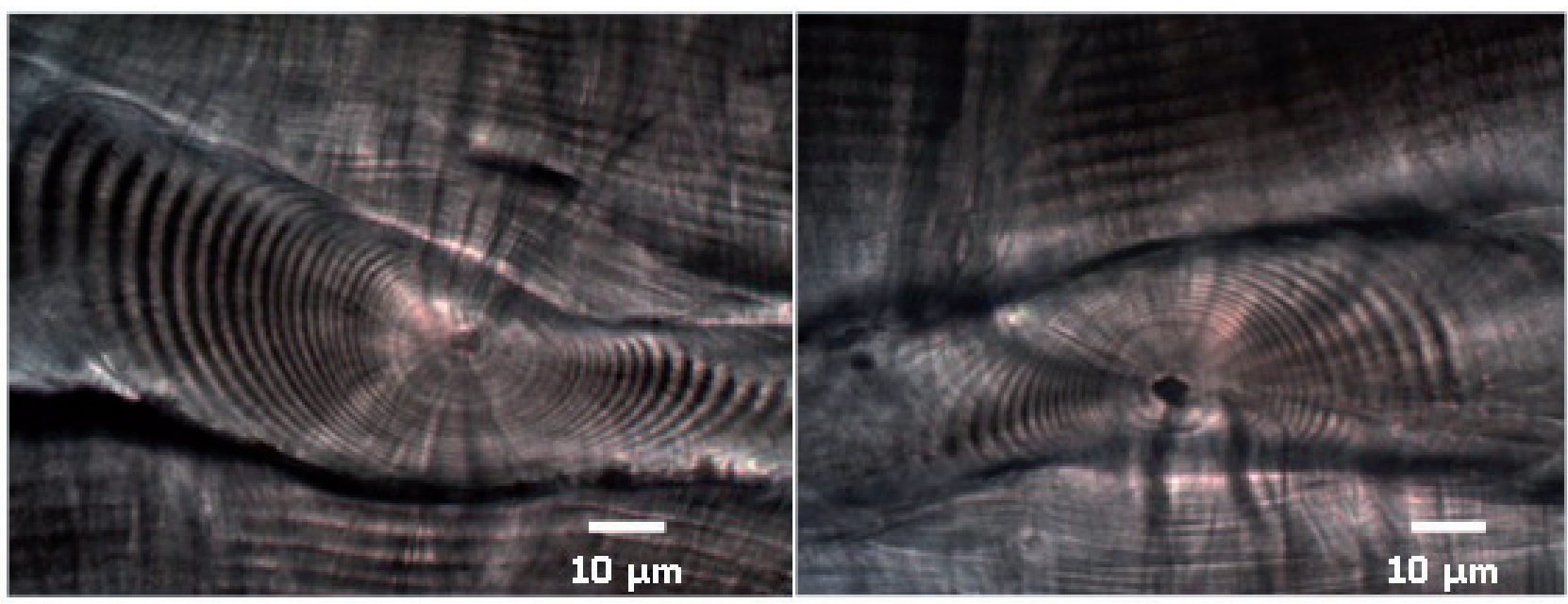

FIGURE 1. Optical microscope photographs (1000X) showing the center of sagittae otoliths in individuals of T. murphyi of $18 \mathrm{~cm}$ (left) and $41 \mathrm{~cm}$ (right) of fork length. / Fotografía en microscopio óptico (1000X) muestra el centro del otolito sagittae en individuos de T. murphyi de $18 \mathrm{~cm}$ (izquierda) y $41 \mathrm{~cm}$ (derecho) de longitud horquilla. 
In the present study, some bias could be observed in the fit of the von Bertalanffy length growth curve in T. murphyi (Fig. 3), with observed data above the fitted curve for fish of 5 years old and older, and below the curve for fish younger than 5 years. Coincidently, old individuals of T. murphyi were more frequently caught by the factory purse seine

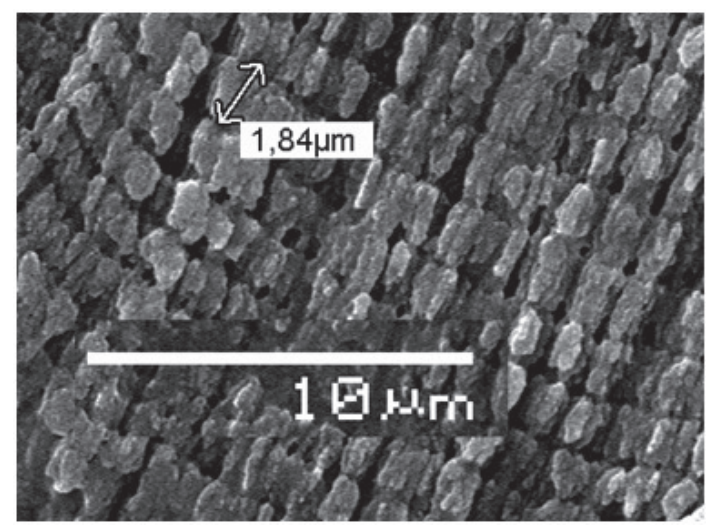

FIGURE 2. Daily ring width of $1.84 \mu \mathrm{m}$ near the border in scanning electron micrographs for a fish of $51 \mathrm{~cm}$ of fork length. / Ancho de un microincemento diario cercano al borde $1.84 \mu \mathrm{m}$ para un pez de $1 \mathrm{~cm}$ de longitud horquilla, micrografía electrónica de barrido. vessels that were operating far from the Chilean Economic Exclusive Zone (EEZ), from $31^{\circ} \mathrm{S}$ to $46^{\circ} \mathrm{S}$ and westwards, where fish are larger and older than within the Chilean EEZ. Then, likely two cohorts of T. murphyi have been combined in Fig. 3. However, in any case the results of the present study are invalid with this likely bias.

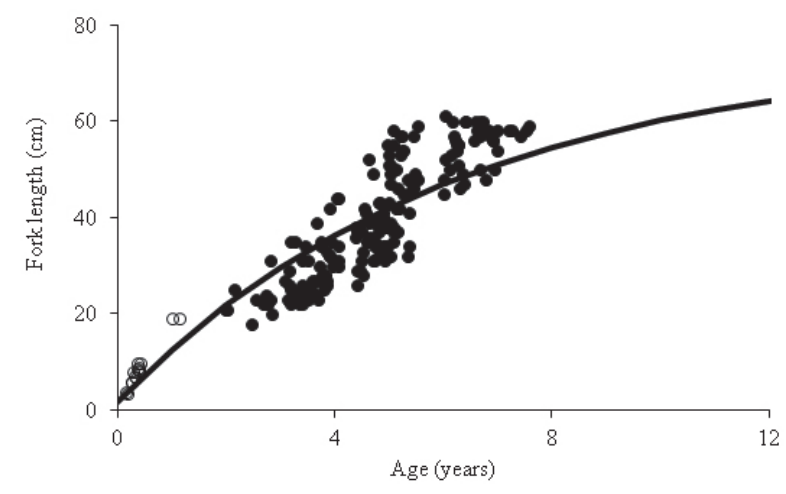

FIgURE 3. Fit of the von Bertalanffy length growth curve in $T$. murphyi. Solid dots: observed data (central Chile; $\mathrm{n}=210$ otholits); open dots: Peruvian data from Anonimous (2014; $\mathrm{n}=17$ otholits). / Ajuste del crecimiento de von Bertalanffy en longitud a $T$. murphyi. Puntos sólidos: datos observados (Chile central; $\mathrm{n}=210$ otolitos); puntos achurados: datos anonimos estimados en Perú (2014; $\mathrm{n}=17)$.

TABLE 1. Length growth parameters of the von Bertalanffy equation estimated for T. murphyi. / Parámetros de crecimiento en longitud de la ecuación de von Bertalanffy estimada para T. murphyi.

\begin{tabular}{lcccccc}
\hline Parameters & Value & Standard Error & t-value & confidence limits & $\mathrm{P}>|\mathrm{t}|$ \\
\hline $\mathrm{FL}_{\infty}(\mathrm{cm})$ & 75.0 & 10.1 & 7.4 & 55.0 & 95.01 & 0.00 \\
$\mathrm{~K}\left(\right.$ year $\left.^{-1}\right)$ & 0.16 & 0.04 & 4.26 & 0.09 & 0.23 & 0.00 \\
$\mathrm{t}_{0}($ years $)$ & -0.13 & 0.17 & -2.73 & -0.47 & 0.22 & 0.01 \\
\hline
\end{tabular}

\section{ACKNOWLEDGEMENTS}

L.C. thanks to Insituto de Investigación Pesquera (INPESCA) for the otolith samples, to CONICYT due to the a grant for M.Sc. studies, and to Postgraduate Division at the Universidad de Concepción due to a scholarship to carry out my studies.

\section{REFERENCES}

Agafonov, A.Y. 1994. Bases oceanográficas de las concentraciones comerciales de jurel en el Pacífico Suroriental, In: Arcos, D., Grechina, A.S. (Eds.) Biología y pesca comercial del jurel en el Océano Pacífico Sur. Instituto de Investigación Pesquera, Talcahuano, Chile. pp.107-111.

Aguayo, M., Estay, E.,. Ojeda, V. 1981. Determinación de edad y crecimiento de jurel (Trachurus murphiy) en las zonas de Arica-Coquimbo y Talcahuano. Informe Subsecretaría de Pesca. Instituto de Fomento Pesquero (IFOP), Chile. pp. $1-88$.

Anonimous, 2014. Annex 04. Final Report, 2014 Jack macerel stock assessment. Scientific Committee, South Pacific Regional Fisheries Management Organization, November. pp. 1-53.

Araya, M., Cubillos, L., Guzmán, M., Peñailillo, J., Sepúlveda, A. 2001. Evidence of a relationship between age and otolith weight in the Chilean jack mackerel, Trachurus symmetricus murphyi (Nichols). Fisheries Research 51: 17-26. 
Araya, M., Medina, M., Arancibia, H. 2003. Preliminary results of the empirical validation of daily increments in otoliths of jack mackerel Trachurus symmetricus (Ayres, 1855) marked with oxytetracycline. Scientia Marina 67: 471-475.

Castillo, G., Arrizaga, A. 1987. Edad y crecimiento del jurel Trachurus symmetricus murphyi (Nichols 1920) en aguas de Chile central. Biología Pesquera (Chile) 16: 19-33.

Cubillos, L.S., Arancibia, H.F. 1994. Comparative growth performance of Jack mackerels of the genus Trachurus, with emphasis on T. symmetricus murphyi in Chile. NAGA, The ICLARM Quarterly 17: 32-35.

Cubillos, L., Grechina, A.S. 1998. Crecimiento del jurel Trachurus symmetricus murphyi (Nichols) del Pacífico Suroriental mediante análisis de progresión modal. In: Arcos, D., Grechina, A.S. (Eds.) Biología y pesca comercial del jurel en el Océano Pacífico Sur. Instituto de Investigación Pesquera, Talcahuano, Chile. pp. 151-161.

Dioses, T. 2013. Edad y crecimiento de jurel Trachurus murphyi en el Perú. In: Csirke, R., Guevara-Carrasco, R., Espino, M. (Eds.) Ecología, pesquería y conservación del jurel (Trachurus murphyi) en el Perú. Revista Peruana de Biología 20: $45-52$.

GrechinA, A.S. 1998. Historia de las investigaciones y aspectos básicos de la ecología del jurel Trachurus symmetricus murphyi (Nichols) en alta mar del Pacífico Sur. In: Arcos, D., Grechina, A.S. (Eds.) Biología y pesca comercial del jurel en el Océano Pacífico Sur. Instituto de Investigación Pesquera, Talcahuano, Chile. pp. 11-34.

Green, B., Mapstone, B., Carlos, G., BegG, G. 2009. Tropical Fish Otoliths: Information for Assessment, Management and Ecology, 1st ed., Springer, Australia.

HoenIG, J.M. 1983. Empirical use of longevity data to estimate mortality rates. Fisheries Bulletin 81: 898-903.

Jensen, A.L. 1996. Beverton and Holt life history invariants result from optimal trade-off of reproduction and survival. Canadian Journal of Fisheries and Aquatic Sciences 53: 820-822.

KAISER, C.E. 1973. Age and growth of horsemackerel Trachurus murphyi of Chile. Transactions of the American Fisheries Society 10B (3): 591-595.

Kochkin, P. 1998. Edad y crecimiento del jurel Trachurus symmetricus murphyi (Nichols) en aguas oceánicas del Pacífico sur. In: Arcos, D., Grechina, A.S. (Eds.) Biología y pesca comercial del jurel en el Océano Pacífico Sur. Instituto de Investigación Pesquera, Talcahuano, Chile, pp. 163-172.

Morales-Nin, B. 1991. Determinación del crecimiento de peces óseos en base a la microestructura de los otolitos. FAO Documento Técnico de Pesca, Número 322, Roma. pp. $1-58$.

Panfili, J., Morales-Nin, B. 2002. Semi-direct validation. In: Panfili, J., Pontual, H. de, Troadec, H., Wright, P. (Eds.) Manual of fish sclerochronology. IFREMER-IRD coedition, Brest. pp. 129-134.

Pannella, G. 1971. Fish otoliths: daily growth layers and periodical patterns. Science 1973: 1124-1125.

Panella, G. 1974. Otolith growth patterns: An aid in age determination in temperate and tropical fishes. In: Bagenal, T.B. (Ed.) The ageing of fish. Unwin Brothers Ltd., Surrey, England. pp. 1-12.

PAULY, D. 1980. On the interrelationships between natural mortality, growth parameters, and mean environmental temperature in 175 fish stocks. ICES Journal of Marine Science 39(2): 175-192.

PAUly, D. 1983. Algunos métodos simples para la evaluación de recursos pesqueros tropicales. FAO Documentos Técnicos de Pesca 234. pp. 1-49.

Pavez, P., SAA, E. 1978. Determinación de edad y crecimiento del jurel Trachurus murphyi Nichols, 1920. Investigaciones Marinas (Chile) 6: 89-100.

Sokolov, V.A., Kusnetsov, A.N. 1994. Historia de la investigación pesquera industrial en el Océano Pacífico Suroriental, In: Arcos, D., Grechina, A.S. (Eds.) Biología y pesca comercial del jurel en el Océano Pacífico Sur. Instituto de Investigación Pesquera, Talcahuano, Chile. pp. 13-17.

Stewart, J., Ferrell, D. 2001. Age, growth and commercial landings of yellow tail scad (Trachurus novaezelandiae) and blue mackerel (Scomber australasicus) off the coast of New South Wales, Australia. N. Z. Journal of Marine and Freshwater Research 35: 541-551.

Waldrom, M., Kerstan, M. 2001. Age validation in horse mackerel (Trachurus trachurus) otoliths. ICES Journal of Marine Science 58: 806-813.

Wetherall, J.A. 1986. A new method for estimating growth and mortality parameters from length-frequency data. Fishbyte 4: $12-14$.

Williams, A., Leroy, B., Nicol, S., Farley, J., Clear, N., KrusicGolub, K., Campbell, D. 2013. Comparison of daily and annual increment counts in otoliths of bigeye (Thunnus obesus), yellowfin (T. albacares), southern bluefin ( $T$. maccoyii) and albacore (T. alalunga) tuna. ICES Journal of Marine Science 70: 1439-1450.

Recibido: 28.04.2017

Aceptado: 30.05 .2017 